\title{
Communication, Context, and Narrative
}

\section{Habermas and Contemporary Realist Thought}

\author{
Navid Hassanzadeh
}

\begin{abstract}
Although often cast by realists as an exemplar of moralist or rationalist thinking, Jürgen Habermas and certain commentators on his work reject this characterisation, highlighting elements of his thought that conflict with it. This article will examine dimensions of Habermas's work that relate to many realist concerns in political theory. I argue that while he escapes the commonplace caricature of an abstract thinker who is inattentive to real world affairs, Habermas's claims in relation to communication, historical and empirical context, and the development of rights in history, reveal a narrow consideration of what defines context and a progressivist narrative of history that fails to address seemingly outdated beliefs and political forces. An analysis of these issues can serve to inform understandings of these topics in realist thought and in political theory more broadly.
\end{abstract}

Keywords: communicative action, context, Habermas, history, human rights, realism

Alongside John Rawls, realists have frequently called attention to Jürgen Habermas's work as illustrative of much of what is wrong with political theory today: the promotion of moralism, rationalism, and general abstraction over and against psychologically rich and politically grounded approaches to thinking. While Rawls has been examined at length within it, reflections on Habermas in realist discourse have consisted mainly of passing references to leitmotifs 
found in his writings, such as ideal speech (Galston 2010: 399; Geuss 2008: 31; Sabl and Sagar 2017: 273; Sleat 2016: 173; Williams 2005: 9-10, 16). The absence of sustained treatment of his work in realist thinking is noteworthy, in part, because according to his own self-understanding, Habermas consciously departs from a theoretical approach that is principally moral-philosophical in nature. For one, he aligns a significant part of his work with sociology and social theory, because of what he sees as general neglect towards the specifics of social and political problems in philosophy (1984: 4-5). He also argues in favour of a broad and complex notion of rationality (10), and explicitly situates his thought 'between' facts and norms (or validity), in his 1992 opus in political and legal theory Faktizität und Geltung (1996: 3-4, 43).

A number of commentators likewise dispute common realist renderings of Habermas's thought. They argue, for instance, that he has consistently theorised in a manner that begins from existing institutions, and social and political circumstances, including those involving power and conflict, rather than philosophical first principles (Chambers 2013: 677; 2018: 268; Cooke 2012: 813; Scheuerman 2013: 803; Strecker 2012: 206-207). In more specific terms, they highlight the interventions that he has made regarding salient political issues in Germany, Europe, and the West more broadly throughout his career as evidence of the fact that he does not fit the guise of an out-of-touch, arm-chair philosopher (Specter 2019: 332; White 2018: 964). Beyond therefore how he himself perceives his work, interpretations of his scholarly and practically political writing offered by others additionally challenge hackneyed representations of Habermas as a moralistic and unrealistic thinker. ${ }^{1}$

This article takes seriously and examines the consequences of Habermas's declared effort to come up with a socially and politically attuned style of democratic theory, and relates this theory to the concerns of recent realist work. I argue that there are two important points to consider regarding this aspect of his thought. First, in introducing a shift towards communication in an understanding of rationality, Habermas both tends to come up with a narrow conception of what makes up social life, and to view political conflict and development primarily through a linguistic lens. As a consequence, he does not adequately acknowledge how empirically grounded approaches to theorising, beyond those focused on communicative 
action, can produce novel theoretical insights, as well as norms of political conduct and values. Second, by fashioning human rights and cosmopolitanism across recent history in a meliorative manner, and by casting his theoretical framework as an optimistic alternative to discouraging takes on the modern era, Habermas tends to ignore or lessen the forms of political harm that do not fit his framework. The result is that he neglects the potential for ostensibly discredited political forces to emerge and subvert his narrative of steady democratisation.

\section{Habermas and Realism}

The contours of political realism today are contested, and in certain respects indeterminate. Some common features nonetheless can be identified and be seen to overlap with basic themes in Habermas's work. In part, realist thought can be defined as a response to interrelated tendencies within contemporary political theory, including an effort to examine politics principally from the perspective of moral issues such as justice or rights. From the point of view of realists, these issues follow from more fundamental forces such as power and political order. If we do not treat the latter as what are integral to political life, we fail to properly understand it (Philp 2012: 631; Sleat 2014: 322-323). Hence Bernard Williams, an author who has posthumously been made into a leading proponent of political realism, argues that the 'first political question' is to secure order, and then to fashion a conception of legitimacy on the basis of it (2005: 3-5). What makes a value such as legitimacy distinct is that it there is no necessary reason to believe that it will be solely or primarily determined by considerations of what is just (Hall 2020: 142). Moral claims are thus understood as integral to theory work, but we should not ascribe overriding importance to them when understanding politics (Geuss 2009: 32; Hall 2020: 13).

One way that realists make this argument is by conceiving of politics as 'autonomous', or as functioning according to its own particular rules and standards, rather than for instance those of ethics, economics, aesthetics, or law (Galston 2010: 391). While some commentators question the notion of autonomy, in particular when it entails a firm division between politics and morality, or what is 
political and pre-political (Douglass 2020: 255-257; Prinz 2020: 80-81; Sabl and Sagar 2017: 272), for others, what is defined as political from such a view is expansive, and the idea helps in avoiding the subordination of politics to other concerns. This means that alongside reason and rationality, we are also motivated by enmity, greed, and anger, emotions that cannot simply be tamed or overcome (Philp 2007: 4-5; Shapiro 2016: 2). Political history as well is not taken to be essentially a story of the gradual unfolding of rationality, as a 'dogmatic Enlightenment' outlook would have it, but an assemblage of competing forces and beliefs, as well as differences and contingencies that separate phases of the past from one another (Geuss 2020: 60-62).

Realists relatedly approach certain 'dark' (Eich and Tooze 2017: $198,215)$ dimensions of rule and social interaction, such as coercion, violent conflict, and domination, as fundamental, either in the sense of being more enduring and important than consensus, peace, and rights, or as being constitutive of all forms of politics, and thus impossible to eliminate (Bellamy 2010: 415-416; Newey 2001: $7-8)$. To be realistic from this perspective means candidly facing the grim features of politics, instead of ignoring them, or euphemistically explaining them away (Geuss 2011: 6; Sleat 2018: 15-16).

This orientation towards facing unappealing political forces and issues stands in tension for Raymond Geuss with prevailing trends in Anglophone political philosophy since the 1970s, for which 'what is common is the systematic exclusion of sociology, real politics, and history, in favour of an appeal to some kind of normativity which is conceived as being contrasted with them' (2016: viii-ix). The problem with such approaches, in addition to lacking attention to what is unseemly, is that they tend towards essentialised conceptions of politics, which neglect historical change and development as regards institutions, values, and arrangements of power (Geuss 2010b: 420). A call for groundedness by contrast does not entail dispensing with normative thinking as such, but rather allowing for context-based investigations to shape how politics is theorised (Thaler 2018b: 24). By proceeding in this manner, realists argue that they avoid misconstruing political problems, and the typologies and classifications related to them, and come up with more accurate (because empirically and historically informed) solutions (Geuss 2008: 9; Szücs 2020: 243-244). 
Finally, realists have an ambiguous and at times conflictual relationship with utopianism. Utopian conceptions of justice, freedom, and rights, from this perspective, are not simply impractical (Hall 2017: 288). On a deeper level, they narrow the scope of what can be brought about in practice by imposing a 'blueprint' to which groups active in politics are forced to reconcile themselves with (Rossi 2019: 644). When invoked, such utopian goals also for some realists serve to mask the particular partisan designs of governing elites and their allies, and the material and symbolic interests that guide their decisions (Geuss 2010a: 39).

Realists are nonetheless not opposed to utopian wishes per se, nor the basic urge for political change underlying them. Accordingly, for Geuss, utopias can and do serve useful ends, in that they address 'human desires and needs that continue to torment us' (2016: 46). Others have adopted a similar line, arguing that there is no ineluctable tension between realist and utopian thinking, and that when understood in a certain way, they can complement one another (McKean 2016: 876; Thaler 2018a: 678; 2019: 1003-1004). Though in order to avoid the abstractions embedded within some utopian imaginings, and to appreciate the socio-political stakes shaping their adoption, we should again be attentive to their different uses, and how historically variable such imaginings are (Geuss 2016: 46-50).

These different features are to varying degrees indebted to previous iterations of realist thinking, either those propounded by mid-twentieth century international relations theorists who impute the realist label to their own work (e.g., Herbert Butterfield, E.H. Carr, Hans Morgenthau), or 'canonical' thinkers who have had the label ascribed to them retroactively (e.g., Thucydides, Niccolò Machiavelli, Thomas Hobbes, Friedrich Nietzsche, and Max Weber). At the same time, recent realist interventions are distinguished by the particular historical circumstances that they are responding to. These include the weakening of the welfare-state, and the corresponding rise in inequality and dwindling of public goods that has accompanied it (Finlayson 2015: 300), and questions related to security and warfare, post-Cold War and in the wake of 9/11 (Sleat 2013: 1). From the perspective of many realists, a narrow-minded preoccupation with issues of justice, and 'the moralism, legalism and parochialism of American Liberal 
theory' (Galston 2010: 386) are inadequate to the task of addressing these and related problems.

It has become axiomatic for realists to associate Rawls's thought with these tendencies. Habermas's work is frequently invoked in such discussions, yet it has not been investigated at length, and in certain respects, he can be said to share the above-mentioned concerns that have defined realism. It is in part for this reason that a number of attempts have been made to reconsider his work in a manner that contrasts with a portrayal of him as a rationalistic thinker who is focused primarily on consensus building and conflict-free speech practices, and who is likewise detached from the workings of real-world politics.

Stephen White and Evan Farr, for instance, call attention to the idea of 'no-saying' (das Nein-sagen-Können), and the broader concept of civil disobedience (of which it is a part) in Habermas's thought, in order to combat what they see as the frequent association of his thinking with a 'great consensus machine' (2012: 32-33). They understand 'no-saying' as an outlet for opposition, embedded within the rule of law, which allows for a conflictual element in communicative action that is 'just as primordial as the understanding-oriented or consensual one' (36). They argue that Habermas's emphasis on this concept, both in his theoretical work and in the political activism that he has engaged in (e.g., his opposition to the stationing of nuclear weapons by NATO in West Germany), allows for a reading of his work that moves beyond the dry proceduralism that it has (wrongly) been reduced to.

Lasse Thomassen similarly looks to civil disobedience in Habermas's work so as to reveal what he sees as the limits of a deliberative democratic paradigm. Thomassen's intervention, which partly inspires the interpretation offered by White and Farr, involves pointing out the 'constitutive imperfectness' of legality, legitimacy, and rationality as they are understood within a democratic context (2007: 201). He invokes Jacques Derrida in articulating this argument and maintains that by dwelling on the perpetually incomplete nature of democratic norms, we are motivated by a healthy dissatisfaction with actually existing political circumstances and arrive at a more vibrant vision of what democracy looks like. Rational consensus in Habermas has an 'aporetic' character, according to Thomassen, whereby it is both the condition and limit of communication, 
and where it becomes the limit, civil disobedience moves in to complement its insufficiency, and motivate political reform (209-10).

While one can appreciate the efforts that these authors make in bringing out under-examined nuances in Habermas's thought, their readings raise the question of whether civil disobedience is as central to his work as they maintain that it is, and if this interpretation speaks more to their own theoretical positions than to his. With regard to the latter question, White and Farr admit as much, claiming that attention to the concept of 'no-saying' in Habermas's works is quite minimal (White and Farr 2012: 51-52), and that the unique interpretation that they offer is more theirs than it is his. They also argue that as a theorist within the Frankfurt School's tradition of critical social theory, Habermas is concerned with questions of power and resistance, and that this focus merits attention to issues beyond consensus and rationality (39). There are however striking differences between Habermas and other 'adherents of this research program', as well as important changes in Habermas's own intellectual trajectory that have translated into an attenuated concern with regard to questions of power (Scheuerman 2002: 75; 2012: 830).

White has more recently reiterated his defence of Habermas against a caricature of him 'as the inventor of the Consensus Machine', abstracted from the messiness of everyday political life (White 2018: 963). According to him, an examination of Habermas's engagements as a public intellectual undermines this depiction. Stefan Müller-Doohm's (2016) biography of Habermas is said to bring this out, and allegedly 'makes it a good deal more difficult for political theorists to continue to blithely purvey this facile image of a passé, ivory tower thinker who is unrealistic about politics and oblivious to its incessant contestation' (White 2018: 964). This is so because, as Müller-Doohm recounts, Habermas takes up a number of causes of key political import in Germany and elsewhere throughout his life (White 2018: 964-965).

Relatedly, Simone Chambers claims that Habermas, and deliberative democrats more generally, by no means abstract from actually existing political problems, and the pluralism and difference that inevitably inform deliberation in contemporary democracies (1996: 158-159). They are said to be closely attentive to exactly these issues, and interested in how their theoretical principles apply to existing political problems (Chambers 2013: 677-678). Peter 
Verovšek similarly argues that in Habermas's political theory work a shift from abstract discussions of truth and validity claims to 'real world debates', related to contestation and opinion-formation in the public sphere, can be discovered, and likewise calls attention to Habermas's emphasis on the pluralism that marks public life (2019: 616-617).

Habermas has undoubtedly long been involved in myriad political causes, including opposition to the Vietnam War, criticism of the emergency measures adopted by the German Federal Republic in response to murders of public officials by the Red Army Faction, and questioning, in debates with German historians, attempts to relativise the atrocities of the Nazis during World War II (Müller-Doohm 2016: 138, 187, 265-266). He has also more recently addressed the European debt crisis (Habermas 2014: 199-201), and the manifestation of far-right nationalism on the continent (Habermas et al. 2018; Habermas 2020), and in many of these interventions, has attempted to demonstrate the applicability of central aspects of his theoretical corpus, such as democratic will-formation.

Commentaries that emphasise these dimensions of this thought serve as useful correctives to crude representations of Habermas as an author who is unconcerned with history and everyday politics. They however do not reveal what a focus on pluralism and contestation may leave out in terms of what practices and forces in democracies are deemed relevant or enduring, nor adequately examine what it means to have practical political concerns inform the construction of theory. Indeed the dichotomy between an abstract, moral-philosophical standpoint, and an empirically grounded, yet still theoretically oriented one, occludes the scope of positions that characterise the latter category, including different value orientations and judgments, historical emphases and blindspots, and analytic techniques and frameworks.

As I will argue, in his circumscribed understanding of context, and largely harmonious account of the advance of democratic freedoms, Habermas both limits the ambit within which politics and history can inform theory, and does not adequately capture prospects of democratic regress. Both points have relevance for realist theory. Its proponents (Geuss 2020: 162-163; Prinz 2020: 67, 80; Sleat 2016: 177) tend to, first, treat invocations of historical or political 
context equally, as preferable to disembodied or ahistorical thinking, without examining the range of standpoints and arguments that emerge from such invocations. Second, in arguing against naively forward-looking, or primarily moralistic, political visions, some devise similarly one-sided schemes, which treat antagonism and coercion in politics as inevitable and unavoidable (Geuss 2008: 96-97; 2011: 6). In this article I argue against Habermas and these realist thinkers for (1) an expansive treatment of context, which does not slip into crude empiricism, and is conscious of the advantages and disadvantages that come with emphasising certain factors over others and (2) for a view of history that eschews neat coherence, and remains alive to both consistency and contingency, or to possibilities for continuity as well as change.

There are a number of critiques of Habermas's democratic theory that, while not explicitly associated with recent realism, resonate with its concerns. He is shown, for example, to overlook that fact that ideal speech as a regulative ideal obscures how power and conflict are essential and not incidental to language (Kohn 2000: 413; Mouffe 2005: 48); to be sparing in diagnosing and responding to actually existing inequalities in Western democracies (Scheuerman 2002: 69); to configure 'discursive rationality' as a 'sanctuary' that is detached from the crisis of the welfare state (Connolly 1987: 71); to come up with a view of our standing as contributors to democratic deliberation that is inattentive to 'unjust social power relations' (Allen 2012: 360-361); and to accept while tempering political conflict, treating it as elite or party-level ‘competition' (Žižek 1999: 28).

Although distinct in important respects, what these critiques have in common is a focus on how Habermas does not sufficiently appreciate the workings and effects of power. The line of criticism that will be taken up below focuses on different emphases, namely context and trajectories of history, which certainly intersect with power, but that also subtend this focus, touching on a different set of realist concerns, and revealing the ways that these concerns shape how power is configured by Habermas and potentially others. They also address the wider set of concerns, beyond those related to power, that Habermas's sympathetic commentators bring out. I demonstrate below why, even on issues where he appears attentive to history and context, problems arise. 


\section{Democratic Practice and Communication}

The most prominent work of Habermas's 'middle period', The Theory of Communicative Action, addresses what he refers to as the 'rationality problematic': how different forms of rational knowledge have shaped belief and action in the West from the early modern period to the twentieth century, and what the effects of these forms are in Western societies of his day. Early in the work, he sets up a distinction between the knowledge represented in these two forms of rationality based on 'the way in which the knowledge is used', the one for 'instrumental mastery' and the other for 'communicative understanding' (11). The former is connected to solving problems and achieving goals (12), and assumes institutional shape through processes of modernising the economy and state, in particular the growth of markets and industrialisation (248). The latter is premised on questioning what constitutes the environment through which such goals can be pursued, and is 'based ultimately on the central experience of the unconstrained, unifying, consensusbringing force of argumentative speech' (10). This 'communicative practice' is moreover embedded in 'an intersubjectively shared lifeworld' (13), or a domain of shared assumptions, beliefs, and cultural bonds that speaking and acting subjects inhabit, and draw upon in order to pursue such understanding.

The lifeworld domain, through which the world is phenomenologically grasped for Habermas, sets the backdrop of communication, and is what the 'conditions of validity' of speech expressions, or the conceptions of truth that rational knowledge aims at, are set against (12-13). These include statements of rightness, truth, and truthfulness, or: whether a claim is right when situated within a broader normative background, if it is true in a way that the knowledge conveyed is acceptable to those who are presented with it, and the extent to which 'intentions, feelings, desires, and the like' of a speaker are considered truthful $(307 ; 2001$ b: 136-137). Normative claims are related to these other forms of validity. They rest not on 'facts' or 'the existence of states of affairs' but on 'the validity of norms' or 'the manifestation of subjective experiences' (1984: 15-16, 308-309).

Habermas includes in this distinction between instrumental and communicative rationality different but overlapping claims as to 
how to apprehend social reality. Although 'for the sake of simplicity' he labels the first 'realistic', the discursive basis of the second does not make it any less grounded in the everyday world. Indeed he describes the communicative form as a 'wider concept of rationality', because it encompasses what is involved in coming to know and act upon one's environment as well as efforts to reach consensual understanding between speaking agents. In other words, it captures for these agents 'both the unity of the objective world and the intersubjectivity of their lifeworld' (10).

Max Weber presents for Habermas the most sophisticated and enduring sociological conception of instrumental rationality. According to Habermas, he accurately portrays the transition from traditional to modern society as one of a broad process of rationalisation, and is correct in observing that the major systems that emerge as a part of this shift (i.e., modern capitalism and bureaucracy) are substructures of its overarching ethos. He errs, though, in Habermas's estimation, by collapsing rationality generally into the purposive/means-ends (zweckrational) form, or the instrumental form that is used in 'non-social situations' (Blau 2019: 3), that he identifies as the driving force behind modernisation. As a consequence, Weber is said to develop a 'noticeable and consequential narrowing of the concept of rationality' (Habermas 1984: 222).

Habermas puts forward a different view through his analysis of the subsystems of money and state-level administration, emphases that align with realist concerns with power and the specific processes involved in societal reproduction. These 'steering media' are mechanisms through which to organise economic and political affairs. They do not operate according to normative standards, such as consensual agreement, but instrumental ones, including market exchange and administrative order (1987: 171-172). The danger that he guards against is the tendency for these material systems to exceed their bounds 'through the monetary redefinition of goals, relations and services, life-spaces and life-times, and through the bureaucratisation of decisions, duties and rights, responsibilities and dependencies', processes that he refers to under the heading of the 'colonization of the lifeworld' (322). The 'rationalization of society' is then not understood along Weberian lines as 'a diffusion of purposive-rational action', but rather as 'the potential for rationality found in the validity basis of speech' (1984: 339). 
Habermas therefore begins his examination of rationality from a specific historical shift, namely transition from the pre-modern to the modern, and analyses this ongoing historical episode from the perspective of concrete processes, material and otherwise. Of note as well is the fact that he calls attention to the forms of power that are created during this transformation, and the social harms that they cause, while wanting to connect this observation and analysis with concern for the modern forms of freedom embodied in communicative practice. He takes up aspects of realist thought while not wanting to allow consideration of the undersides of modernity and modernisation to overshadow the liberatory dimensions that can also be identified with them.

In Between Facts and Norms Habermas extends his conception of rationality to law, arguing that the idea 'absorbs the tension between facticity and validity into its fundamental concepts' (1996: 8), meaning that it incorporates empirical processes of societal reproduction, as well as exercises in reflection or contemplation orientated towards intersubjective understanding. To this extent, he addresses the coordination of action and social integration that are not guaranteed for him through communication alone (42). Law brings together 'the reproduction of social life' and 'the idea of a conscious conduct of life', as 'integration is based simultaneously on the threat of external sanctions and the supposition of a rationally motivated agreement' (1996: 8). With the latter he has in mind discursive will-formation, which relies on 'self-legislation by citizens' where 'those subject to law as its addressees can at the same time understand themselves as authors of the law'. This involves a process of fashioning oneself as a rights-bearing citizen by activating the rights that are initially bestowed upon subjects by the law or a political legislator (120).

In discussing tensions between facticity and validity in the law, Habermas contrasts his position with Rawls's. He submits that Rawls overlooks the tension 'internal' to the law, or the acceptance of legal norms and their legitimation through self-legislation (39), and the 'external' tension between legitimate rules and the social practices that coordinate and sanction personal conduct in accord with the law (64). This is the case for Habermas because Rawls does not examine how his principles of justice are institutionally applied (1997: 132). The implication here is that he is inattentive to how existing social structures shape and constrain the realisation of 
these principles in the real world. Habermas portrays his position as alternatively cognisant of such constraints, not falling victim to the impractical imaginings that Rawls does, all the while avoiding the opposite tendency of reducing the law to being a function solely of its coercive capacities (1996: 64-65).

Along these lines, Habermas's shifts to communicative rationality and will-formation through the law are also a response to 'empiricist theories of power' (289). Such approaches for him focus excessively on the struggle for and organisation of rule, at the expense of attention to the principles upon which such rule should be based. Not unlike his attempt to balance instrumental and communicative rationality, he acknowledges the role of the coercive power of the state in punishing 'norm violations', and in enforcing order (Baxter 2011: 85-86; Habermas 1996: 133), but lends to such power a vision of legitimacy, which is produced by processes and procedures including communication and will-formation (Habermas 1996: 288).

While such a proceduralist approach to political conduct may appear to be 'freighted with idealizations', Habermas cautions against such an interpretation. He rejects a neat divide between theory and practice, proceeding not from abstract normative principles, but from the deliberative exercises of citizens, as it is the latter that provide the substance of norms (287; Von Schomberg and Baynes 2002: 6). Habermas therefore clearly understands communicative action, alongside the rule of law, as situated within real-world democratic practices. Moreover, he envisions such a theory as one that avoids the 'normative defeatism' of certain sociological approaches that focus on power as a competition of wills, or a self-contained system of administration that reproduces itself on its own (1996: 330).

His analysis in Between Facts and Norms can be interpreted as broadening his earlier investigations into the divide between instrumental and communicative rationality. Noteworthy though is that while connecting normativity to empirical reality, Habermas understands that reality, or 'social facticity', above all through communicative practices, or manifestations of reason. This bounded approach leaves out of consideration a broader array of factors that can be associated with historical and contemporary contexts, or empirical reality, a focus upon which could potentially give rise to other ways to conceive of norms and values, or to the perception of different sets of problems in modern life. 
This perspective is illustrated towards the end of The Theory of Communicative Action, where Habermas interprets a number of contemporary societal antagonisms as the result of stifled modes of speech. In the concluding sections of the work, he addresses social movements and forms of protest directed against the welfare state in Western democracies in the 1960s and '70s, and argues that what is important about such movements is that they eschew conventional lines of protest, and the institutional forms of organisation that have accompanied them in the past. They no longer focus, in his reading, on traditional concerns of 'security', whether economic or military, but rather 'quality of life, equal rights, individual selfrealisation, participation, and human rights' (1987: 392). When commenting on this shift, Habermas interprets such struggles as 'a reification of communicatively structured domains of action', and 'questions having to do with the grammar of forms of life' (392) without detailing how this is the case, or whether or not this linguistic outlook forecloses other explanations of what motivates social movements of the era.

Habermas adopts a similar stance when explaining the attacks of 11 September 2001. He remarks that many have asked him whether or not his model of communicative action 'has been brought into disrepute' because of a seeming disconnect between what caused these attacks and the explanatory thrust of his philosophy, and responds by disputing the suggestion. He on the one hand emphasises the importance of different forms of structural violence in Western societies, while on the other arguing that contemporary manifestations of violent conflict in the West, or between the West and the non-Western world, result in a fundamental sense from 'distortion in communication, from misunderstanding and incomprehension, from insincerity and deception' (2003: 35) Although it may be plausible that at some level, complications in basic understanding lie at the root of different conflicts, the destructiveness of 9/11 for him is essentially understood in linguistic or communicative terms (Ashenden 2014: 443-444). The broader circumstances wherein this violence occurs, which include wealth inequality and poverty, war and other forms of military expansionism, and the repressive tactics of liberal and authoritarian rule, are overlooked or downplayed by Habermas, as are other, non-linguistic, causes and solutions to it. 
Habermas's reflections raise the question of what it means for a theory of law and democracy to be socially grounded. He presents his approach as such. Left unquestioned though is the assumption that theoretical groundedness corresponds to a focus on communicative practices (1984: 139-140). In largely restricting his understanding of facticity and empirical reality to these practices, Habermas does not take into account a wider conception of what makes up different contexts.

This can be further seen in his thoughts on the recent global rise of the far-right, including the German Alternative für Deutschland (AfD). In part, Habermas explains the emergence of the group with reference to increasing levels of poverty and inequality, especially in regions of the former East Germany, and a corresponding sense of powerlessness in the face of unaccountable decision-making patterns of EU elites (2020: 8-10). Underlying these issues, though, is for him a problem of societal integration, or the tension between values and practices of intersubjective understanding on the one hand, and systems-processes on the other. He places emphasis on the first when reflecting on right-wing extremism today, arguing that what is needed is a process where dominant society with its democratic norms learns to welcome marginalised groups (i.e., the poor, minorities, and immigrants) (11-13). The attraction of some Germans to the AfD must be understood for him as wrongheaded yearning for an allegedly forlorn past that preceded these processes of inclusion, and that are exacerbated by socio-economic insecurity (13).

While he touches on different factors behind the rise of the farright over the past several years, he centres democratic institutions and the communicative practices underlying them when analysing the problem. An alternative approach could begin from the discourses and policies of the AfD, and situate them within a deeper historical setting of xenophobia and racism. This would include the past and consequences of German colonialism in southwest Africa, the long-standing marginalisation of and denial of rights to migrant 'guest workers' (and their descendants) from southern Europe, Turkey and the Maghreb, the insecure legal status of civil war refugees from Somalia, Lebanon, and beyond, and the recent growth of other far-right groups and movements in Germany such as the National Socialist Underground (NSU) and PEGIDA (El-Tayeb 2001: 
16-19, 62-66; 2011: 21-27; 2018: 86-88). From this perspective, the issue would not be one of self-correction for essentially robust, rationalised integration processes. It would instead be coming to terms with consistent legacies of wrongdoing against colonial subjects, immigrants, and racialised minorities, and how extreme and intolerant right-wing forces have often co-existed alongside liberal institutions and political culture.

For many realists, context is turned to in order to avoid the problems of abstraction, such as thought schemes with poor explanatory value. Theorists promoting such schemes are believed to be inattentive to the richness and nuances of history, with the constraints and possibilities that are contained therein (Geuss 2016: 2-3). The problem is that what is involved in invoking context often goes unexamined in realist literature. What Habermas's treatment of these different examples (1960s/'70s protest movements, 9/11, contemporary far-right extremism) reveal is that in focusing his democratic theory on social life, with attention to the steering systems of money and state-level administration, and an emphasis on the tensions between facticity and validity built into the law, Habermas can be said to seek after such a balance. He is thus sensitive to at least certain threats to modern freedom, understood as systemic pressures against communicative rationality and democratic will-formation. $\mathrm{He}$ is simultaneously overly focused on communicatively mediated social processes and the dangers built into steering systems, and not able to discern other dangers and relevant facts with the same degree of theoretical acuity. The result is that he forsakes an ability to better capture, explain, and solve social problems in all of their variety and complexity. It is in this sense that his scheme can be said to assume an air of unreality, because of what it leaves out, and the interpretive costs that follow from such omissions.

The process of 'delimiting the relevant context' (Koskenniemi 2014: 124) of historical or social scientific work will inevitably involve selectivity regarding what to examine or investigate. For Habermas, however, the problem is not solely one of selectivity or perspectivalism, but of how the work of discerning what is worthy of analysis is carried out. He invokes a similar set of criteria related to how rationality is developed and deployed in a communicative manner, instead of flexibly responding to what different contexts present. Doing the latter can lead to investigations into 
what elements of context are germane when addressing problems, and what can distract, mislead, or more modestly, only provide partial clues to responding to such problems. It is precisely from such a consideration of the richness of context that certain forms of theorising are made possible. By overextending a focus on communicative practices and obstacles to linguistic understanding, Habermas relinquishes such potentials.

\section{Legality and Rights}

Matthew Specter claims that Habermas's focus on the rule of law can be understood as a reflection of his worries about threats to radically undermine legal structures in twentieth-century Germany. Habermas's intellectual coming-of-age during the post-war period was marked, like that of his German academic counterparts, by the need to explain the emergence of the Third Reich on cultural and philosophical levels, and to devise a way to avoid the re-emergence of similar political forces (Specter 2010: 6). In legality, and legal frameworks, Habermas finds a solution to the excesses of Nazism that would provide a liberal foundation to German democracy, one that is more sustainable than the illiberal mode that emerged in the country in the 1930s (13).

Legal validity is derived from the practices of discursive willformation described in the previous section. Through this approach, Habermas connects discourse ethics to democracy. Beginning with the abstract principle of a right to uncoerced, individual liberty, he proceeds to insert this idea into legal institutions and the procedures associated with them. Through the practice of discursive will-formation, the individual autonomy that at first carried a purely theoretical quality is now endowed with a complex legal character because of what selflegislation by individual citizens contributes to it (1996: 121-122).

Habermas (1996) introduces again, in the context of this analysis, the tension between facticity and validity, this time in relation to law and politics. On the one hand, 'political power' (i.e., the judicial and executive branches of the state) is 'presupposed by law' in the sense of being created and sanctioned by 'legitimately enacted law', or that brought about by the procedures of popular will formation and the representative institutions though which it is expressed 
(134-135). On the other, that same power political power is 'backed by the instruments of force held in reserve', while also 'authorized by legitimate law' (136). The legally authorised state, or Rechtsstaat, is the product for Habermas of efforts to guarantee rights-protections and avoids the arbitrariness of sovereign whims as well as the flimsiness of abstract considerations of justice (32-33, 58-59).

Human rights embody this legalistic achievement and maintain the balance between facticity and validity for him internationally. He describes them for instance in a recent work as 'a realistic utopia'. Human rights can be made sense of in this manner because they are not premised upon quixotic ideals of 'collective happiness', but instead are situated in the institutions of liberal-democratic states, and international organisations such as the United Nations, as well as the normative foundations underlying them (2017: 95). These include the Universal Declaration of Human Rights and key provisions of different German constitutions from the mid-nineteenth to the mid-twentieth century (71-78). Human rights as a realistic utopia are also driven by 'social movements and political struggles' that shed light on a variety of abuses and violations in Western and non-Western states alike (94-95).

Habermas recognises that part of the problem with how human rights are conceived relates to the manner in which they are practically realised. They can and often have been deployed as covers for the partisan interests of powerful states, under the auspices of 'a non-representative and far from impartial [UN] Security Council' (96). Although the tendency to abuse human rights, through preemptive war and in contravention of international legal norms, does not exhaust their meaning and potential for him. To fashion human rights as a realistic utopia entails being aware of these dangers, while not reducing them to distortions in practice (97-98).

Habermas's view of history here is informed by his conception of democracy as a process of 'learning from the past'. Again, for his generation in Germany, this meant grappling with the Nazi period, and with a selective historical imagination during the post-war era (1997: 11; 1999: 271). While he argues that there are 'no theoretically satisfying answers' to the question of what concrete lessons can be derived from history, he does hold that past precedent can reveal to us what 'not to do', and to rethink views that were previously believed to be authoritative (1997: 11, 13). 
In a similar vein, Habermas contrasts his thinking with that of a number of authors and intellectual trends, including Weber, Carl Schmitt, first-generation Frankfurt School theorists, and Nietzsche- and Heidegger-inspired post-modern approaches to philosophy (Habermas 1987: 312; 1998: 338-339; Cooke 1994: ix). Common amongst these different figures and styles of thinking, in his estimation, is the tendency to come up with grim or despairing outlooks on the modern era, focused disproportionately on forces of domination that manifest in problems like a hyper-administered lifeworld. Their solutions for him likewise reveal shortcomings, as they consist of either minimally political, aestheticised alternatives, or strategies that concentrate power amongst unaccountable political leaders (1987: 333).

Müller-Doohm argues that vital to Habermas's evolution as a thinker has been resistance to dim conceptions of the development of history, which are believed to be premised upon 'absolute negativity' in modern existence (2016: 4). Precisely such conceptions can be perceived for him in the works of these different thinkers. Habermas's response to the seeming impasses of these theoretical framings is to stress redeeming features of modern politics, such as self-governance and rights, as realised through communicative practices (1984: 390). Habermas fashions this aversion towards despairing treatments of modernity as reasonable and hopeful. The problem is that this stance leaves him ill-suited to diagnose and address certain political challenges or harms. This can be seen for instance in his theorisation of human rights, which reveals an essentially optimistic conception of history, as he argues in favour of identifiable development in the direction of peaceful and cooperative relations among states.

Human rights are understood according to his view as an indication of a broader process through which international affairs come to mirror the development of the Rechtsstaat in European modernity. The latter is said to have 'contained despotism' in the domestic sphere, while the 'juridification of international relations' post-WWII has a similar effect on a global scale, where practices of shared governance and consensus increasingly become the norm, and politics becomes less arbitrary and violent (2015: 51). A range of international organisations formed since the founding of the UN - e.g., the G20, G8, World Trade Organization, World Bank, and International Monetary Fund - are also seen as bearing the marks of this juridification. In these as well as similar bodies of governance 
beyond the nation-state, one can witness the 'further dissolution of the decisionistic substance of the power involved in the exercise of political authority' (52, emphasis in original).

The most remarkable indication of this development towards juridification and international peace for Habermas is the decreasing use of war as a tactic to settle disputes. 'The fact that war', he writes, 'is neither a legal nor the preferred means for solving international conflicts in our post-heroic age is only the most visible sign of a rationalisation of the violence at the core of political power' (54-55). His view of the transformation of relations between states away from violence and bellicosity begs the question of what is left out of such a vision. While there may be less reliance on kinetic military action in certain scenarios, a number of Western and nonWestern states have continued the practice of warfare, through for instance outsourcing combat to other countries and forces, the manufacture and sale of arms, the maintenance of military bases, the imposition of economic sanctions, and the use of new technologies such as drones. These examples make questionable any claims as to the 'rationalization of violence at the core of political power'. They also reveal theoretically how Habermas's meliorative view of history leads to inattention to practices and events that do not fit into the trajectory that he traces. They are either ignored by him, or framed as aberrations, and their consequences in politics are correspondingly downplayed.

In other words, when processes and events take place that are discordant with his alleged learning process, Habermas's urge is to de-emphasise their impact. He instead stresses the pacific tendencies that are the hallmark of his vision of international law, including how the growing interdependence of the world has supposedly meant that states are 'forced to cooperate' and that 'the decisionistic core of political power is being broken down once again in the crucible of the communicative currents of transnational negotiations and discourses' (2015: 55). In coming up with this positive vision, Habermas develops a pattern of thought that does not sufficiently address the staying power of seemingly obsolete beliefs, practices, and institutions, as well as the pernicious aspects of liberal and progressive ones.

It could be argued in response that Habermas's understandings of rights and legitimate law-making represent limit conditions. 
This can be seen in how he theorises democratic will-formation. In order to function properly, such an outcome assumes 'communication flows that start at the periphery' and then shape and are taken through the procedures and institutions of parliamentary government. He qualifies this model, however, writing that 'the normal business of politics, at least as it is routinely conducted in Western democracies, cannot satisfy such strong conditions' (1996: 356). Not dissimilar to how he has revised his view of ideal speech, framing it not as a model to be concretely put into practice but as a 'counterfactual' (1982: 261-262; 1996: 4), his general conception of law and politics, from this standpoint, should not be understood as a blueprint to realise, but rather something to be approximated, and used as a guide for democratic exercises.

This more modest framing though does not alter his inattention towards reversals in political practice. Habermas maintains a forward-looking vision, concentrated on deepening and strengthening existing rights and institutions. His treatment of the constitution as 'an unfinished project' clarifies this point further. 'The constitutional state', he writes, 'does not represent a finished structure but a delicate and sensitive - above all fallible and revisable - enterprise, whose purpose is to realise the system of rights anew in changing circumstances, that is, to interpret the system of rights better, to institutionalise it more appropriately, and to draw out its contents more radically' (1996: 384).

The project of the constitutional state remains open, yet political development is fixed in a singular direction. Habermas only foreshadows positive transformations, where fundamental reinterpretations of what makes up such change are omitted, as is attention to political forces that undermine such a constitution and related institutions. Even when he does allow for 'contingent interruptions and historical regressions' (2001a: 774) in struggles over constitution making, these are represented as minor caesurae in an otherwise forward-marching advance of democratisation. As Bonnie Honig points out, allowance of these ruptures is couched 'in an otherwise secure trajectory of progress', which 'leaves us unprepared for the reemergence of old claims that were thought to be discredited; it leaves us unprepared for the appearance of ressentiment' (2006: 167).

Habermas responds similarly to the recent rise of the far-right in Europe. When asked if this phenomenon and other recent threats 
to liberal-democracies have led him to question his previouslyheld 'optimism for progress' (Fortschrittsoptimismus) concerning modernity, he responds: 'These signs of a political regression in Western democracies are worrisome. Yet I see neither an alternative to our constitutional principles that can be justified in a normatively persuasive way, nor a stable form of "illiberal democracy" that, in the long-term, would be compatible with the functional needs of modern societies' (Habermas 2020: 19 - emphases in original, translation mine). An inclination towards minimising the impact of these groups in the short-term is revealed here, as is a tendency to discount the ways that far-right leaders, movements, and party coalitions can and have reconciled themselves with, and indeed long-shaped, the alleged 'functional needs' of governance in the West.

One way to summarise these complications would be to maintain that Habermas fails to put forth an adequately sordid conception of history and politics. It may be true that recent realists adopt some such standpoint, where 'politics properly understood just is power, struggle, conflict, interest, competition, violence, and coercion' (Chambers 2013: 678), and Habermas clearly rejects such a view. The issue, however, would not be to pose a cynical interpretation of the present and future as an alternative, nor to dwell in coercion and domination as inevitable and unavoidable. Such a vision would simply be the converse of a fundamentally idealistic outlook, which supplants one set of predetermined foci for another. Thinking otherwise would in other words not only assume a desire to bring out the rougher edges of politics. In keeping with an expectation to remain phenomenologically grounded as a starting point for theoretic analysis, what would be needed is a sufficiently broad outlook that does not a priori privilege some social and political forces as more durable and meaningful than others.

A certain coherence-of-narrative may be part and parcel of the first-order theorising that has long characterised Habermas's work. The urge to highlight certain facts and themes above others would on the face of it then not be questionable. What would be is a narrative that downplays or obscures subject matter and concerns that are incongruous with it. In the interest of avoiding certain practical and theoretical dead-ends, this is the direction in which Habermas tends. It is as if allowing for consideration of revanchist trends 
opens the door to a wholly dehumanised existence, in which talk of freedom has been rendered meaningless, and our capacities to critically assess our social reality for the better have been impaired.

Therefore, minimising factors that militate against a harmonious narrative could be as problematic as an undue focus on them. A different perspective would have to avoid the progressivist kernel that structures Habermas's framework of the evolution of rights, communicative reason, and cosmopolitanism in history. It would be open to the potential for backtracking and contingencies, alongside consistency and advancement. Instead of clinging to the darker dimensions of politics, such a standpoint could be seen as a complement to those that leave such circumstances out of consideration.

\section{Conclusion}

A close examination of Habermas's thought reveals a thinker who is more complicated than common realist depictions would have him appear. He often proceeds from actually existing social and political circumstances, draws from history, and derives crucial features of the normative content of his thought from the practical experiences of democratic citizens. It is these same dimensions of Habermas's work, however, that reveal a host of problems related to his approach to real-world politics, which are relevant to an understanding of his own thought as well as of political theory and realism more generally.

The idea of context tends to be invoked with frequency in realist literature. Doing so reveals a clear benefit that it as a style of thought has over purportedly detached approaches to theorising (Geuss 2008: 9-11, 13, 59-60, 99). In contrast to these other schemes, realists are said to operate within particular places and time periods, and as a result, to be more responsive to the interests and demands of different populations, thus avoiding the pitfalls of false universalisms or absolutes. A straightforward appeal to context in an undifferentiated manner, however, can muddle more than clarify.

Although Habermas identifies his position as one that is situated within definite contexts, it is frequently only a narrow slice of circumstances that is brought out, namely that related to 
communication and the conditions for properly achieving it. Such a dominant referent is helpful in calling attention to certain features of modern politics. It also clearly involves inattention to others, and it is these other factors that are slighted when he labels his position as one that is contextually embedded.

A full accounting of all elements of a given historical or empirical context is inconceivable. This need not, though, lead to questioning meaningful claims and judgments about politics as coming from 'an imperfect inquirer', because our knowledge of context is seen as necessarily 'ongoing and provisional' (Schlosser 2014: 257). One can question what elements of a context are more worthy of consideration than others, what is lost or gained in making such a judgment, and how the different components of context change over time, without giving oneself over to essential uncertainty or a narrow range of vision. The issue then becomes less whether or not one's theory is actually located in a given context, nor how concrete or granular on the one hand, or limited, on the other, one's contextual perspective is, but what choices one makes in determining what actually constitutes the 'realities of politics' (Edyvane 2020: 283), and the benefits and liabilities involved in such decisions.

Habermas's deliberate presentation of his thought at the meeting point between reason and facticity portends a balanced appreciation of both. Yet the historical narrative of learning from the past that he promotes, in addition to his effort to gain distance from the apparent stalemates of melancholic thinking, leave him ill-equipped to speak to the resurgence of supposedly outdated views, excesses, and wrongs. Without allowing it to become an excessive preoccupation of political thought, a sceptical disposition can be helpful in this respect. Openness to such a disposition regarding the evolution of democracy, in contrast with naïve optimism about its growth, would enable a sober appreciation of struggles and achievements, and render openly visible the discomfiting realities that continue to haunt collective life.

\section{Acknowledgements}

I would like to thank Richard Boyd, R. Bruce Douglass, and the anonymous peer reviewers for their helpful feedback on previous drafts of this article. 
NAvid HassanZadeH is an assistant professor in the Department of Political Science at Towson University. He has research interests in comparative political theory, social theory, and the history of political thought. E-mail: nhassanzadeh@towson.edu

\section{Note}

1. Raymond Geuss has recently argued that Habermas's communicative theory leads to an abstract, strongly ethical, approach to politics. While Geuss has made major contributions to recent realist literature, by his own admission in the context of this discussion, his reading of Habermas is not one that closely engages with his works. I put forth an assessment of his thought here that offers such an engagement. For Geuss's recent intervention and debate with others on this question, see: Geuss, 'A Republic of Discussion: Habermas at Ninety', The Point 18 June 2019 https://thepointmag.com/politics/a-republic-of-discussion-habermas-at-ninety/; Seyla Benhabib, 'Jürgen Habermas's Ninetieth Birthday', Medium 2 July 2019 https://medium.com/@arendt_center/j\%C3\%BCrgen-habermass-90th-birthday2c2a720a4f5b; Martin Jay, “The Liberal Idea Has Become Obsolete”: Putin, Geuss, and Habermas', The Point 5 July 2019 https://thepointmag.com/criticism/ the-liberal-idea-has-become-obsolete-putin-geuss-and-habermas/; Geuss, 'Professor Benhabib and Jürgen Habermas', Medium 7 July 2019 https://medium.com/@ arendt_center/professor-benhabib-and-j\%C3\%BCrgen-habermas-2e3fd50e1147.

\section{References}

Allen, A. 2012. 'The Unforced Force of the Better Argument: Reason and Power in Habermas's Political Theory'. Constellations 19 (3) : 353-368.

Ashenden, S. 2014. 'On Violence in Habermas's Philosophy of Language'. European Journal of Political Theory 13 (4) : 427-452.

Baxter, H. 2011. Habermas: The Discourse Theory of Law and Democracy. Stanford, CA: Stanford University Press.

Bellamy, R. 2010. Dirty Hands and Clean Gloves: Liberal Ideals and Real Politics. European Journal of Political Theory 9 (4): 412-430.

Benhabib, S. 2019. Jürgen Habermas's Ninetieth Birthday. Medium. https:// medium.com/@arendt_center/j\%C3\%BCrgen-habermass-90th-birthday2c2a720a4f5b;

Blau, A. 2019. Habermas on Rationality: Means, Ends and Communication. European Journal of Political Theory DOI: 10.1177/1474885119867679.

Chambers, S. 1996. Reasonable Democracy: Jürgen Habermas and the Politics of Discourse. Ithaca, NY: Cornell University Press.

Chambers, S. 2013. 'Book Review: Political Philosophy Versus History? Contextualism and Real Politics in Contemporary Political Thought, eds. Jonathan Floyd and Marc Stears'. Political Theory 41 (4): 676-683. 
Chambers, S. 2018. 'Kickstarting the Bootstrapping: Jürgen Habermas, Deliberative Constitutionalism and the Limits of Proceduralism', in R. Levy, H. Kong, G. Orr, and J. King (eds), The Cambridge Handbook of Deliberative Constitutionalism. Cambridge: Cambridge University Press, 256-268.

Connolly, W. 1987. Politics and Ambiguity. Madison, WI: University of Wisconsin Press.

Cooke, M. 1994. Language and Reason: A Study of Habermas's Pragmatics. Cambridge: MIT Press.

Cooke, M. 2012. 'Realism and Idealism: Was Habermas's Communicative Turn a Move in the Wrong Direction?' Political Theory 40 (6): 811-821.

Douglass, R. 2020. 'Hobbes and Political Realism'. European Journal of Political Theory 19 (2): 250-269.

Edyvane, D. 2020. 'Who's the Realest?' European Journal of Political Theory 19 (2): 281-290.

Eich, S. and A. Tooze. 2017. 'The Allure of Dark Times: Max Weber, Politics, and the Crisis of Historicism'. History and Theory 56 (2): 197-215.

El-Tayeb, F. 2001. Schwarze Deutsche: Der Diskurs um 'Rasse' und nationale Identität 1890 - 1933. Frankfurt: Campus.

El-Tayeb, F. 2011. European Others: Queering Ethnicity in Postnational Europe. Minneapolis, MN: University of Minnesota Press.

El-Tayeb, F. 2018. 'Oppressed Majority: Violence and Muslim Communities in Multicultural Europe', in S. Daulatzai and J. Rana (eds), With Stones in Our Hands: Writings on Muslims, Racism, and Empire. Minneapolis, MN: University of Minnesota Press: 84-101.

Finlayson, A. 2015. 'From Theorising Realism to the Reality of Theory: A Response to Adrian Little'. Contemporary Political Theory 14 (3): 295-304.

Galston, W. 2010. 'Realism in Political Theory. European Journal of Political Theory 9 (4): 385-411.

Geuss, R. 2008. Philosophy and Real Politics. Princeton, NJ: Princeton University Press.

Geuss, R. 2009. 'What is Political Judgment?' In R Bourke and R Geuss (eds), Political Judgment: Essays for John Dunn. Cambridge: Cambridge University Press: 29-46.

Geuss, R. 2010a. Politics and the Imagination. Princeton, NJ: Princeton University Press.

Geuss, R. 2010b. Realismus, Wunschdenken, Utopie. Deutsche Zeitschrift für Philosophie 58 (3): 419-429.

Geuss, R. 2011. Wer das Sagen Hat: Einige Überlegungen zum politischen Status von Autorität. Mittelweg 3620 (6): 3-12.

Geuss, R. 2016. Reality and its Dreams. Cambridge, MA: Harvard University Press.

Geuss, R. 2019a. A Republic of Discussion: Habermas at Ninety. The Point. https://hepointmag.com/politics/a-republic-of-discussion-habermas-atninety/ 
Geuss, R. 2019b. Professor Benhabib and Jürgen Habermas. Medium. https:// medium.com/@arendt_center/professor-benhabib-and-j\%C3\%BCrgenhabermas-2e3fd50e1147.

Geuss, R. 2020. Who Needs a World View? Cambridge, MA: Harvard University Press.

Habermas, J. 1982. 'A Reply to My Critics', in J. B. Thompson and D. Held (eds), Habermas: Critical Debates, trans. T. McCarthy. Cambridge, MA: MIT Press.

Habermas, J. 1984. The Theory of Communicative Action Volume I Reason and the Rationalization of Society, trans. T. McCarthy. Boston, MA: Beacon Press.

Habermas, J. 1987. The Theory of Communicative Action Volume II Lifeworld and System: A Critique of Functionalist Reason, trans. T. McCarthy. Boston, MA: Beacon Press.

Habermas, J. 1996. Between Facts and Norms: Contributions to a Discourse Theory of Law and Democracy, trans. William Rehg. Cambridge, MA: MIT Press.

Habermas, J. 1997. A Berlin Republic: Writings on Germany, trans. S. Rendall. Lincoln, NE: University of Nebraska Press.

Habermas, J. 1998. The Philosophical Discourse of Modernity: Twelve Lectures, trans. F. Lawrence. Cambridge, MA: MIT Press.

Habermas, J. 1999. 'Bestiality and Humanity: A War on the Border Between Legality and Humanity', trans. S. Meyer and W. Scheuerman. Constellations 6 (3): 263-272.

Habermas, J. 2001a. 'Constitutional Democracy: A Paradoxical Union of Contradictory Principles?' Trans. W. Rehg. Political Theory 29 (6): 766-781.

Habermas, J. 2001b. Moral Consciousness and Communicative Action, trans. C. Lenhardt and S. Weber Nicholsen. Cambridge, MA: MIT Press.

Habermas, J. 2003. 'Fundamentalism and Terror: A Dialogue with Jürgen Habermas', in G. Borradori (ed), Philosophy in a Time of Terror: Dialogues with Jürgen Habermas and Jacques Derrida. Chicago, IL: University of Chicago Press.

Habermas, J. 2014. 'Merkel's European Failure: Germany Dozes on a Volcano', trans. C. Sultan. Constellations 21 (2): 199-201.

Habermas, J. 2015. 'Keywords on a Discourse Theory of Law and of the Democratic Constitutional State'. In The Lure of Technocracy, trans. C. Cronin. Cambridge: Polity Press: 46-60.

Habermas, J. 2017. 'The Concept of Human Dignity and the Realistic Utopia of Human Rights'. In: The Crisis of the European Union: A Response, trans. C. Cronin. Cambridge: Polity Press.

Habermas, J. 2020. Moralischer Universalismus in Zeiten politischer Regression. Leviathan 48 (1): 7-28.

Habermas J. et al. 2018. 'We are deeply concerned about the future of Europe and Germany'. Handelsblatt Global www.handelsblatt.com/ today/opinion/time-to-wake-up-we-are-deeply-concerned-about-thefuture-of-europe-and-germany/23583722.html?ticket=ST-506107bIGqlrx1aQ3bV7iyajw6-ap6. 
Hall, E. 2017. 'How to do realistic political theory and why you might want to'. European Journal of Political Theory 16 (3): 283-303.

Hall, E. 2020. Value, Conflict, and Order: Berlin, Hampshire, Williams and the Realist Revival in Political Theory. Chicago: University of Chicago Press.

Honig, B. 2006. 'Dead Rights, Live Futures: On Habermas's Attempts to Reconcile Constitutionalism and Democracy', in L. Thomassen (ed), The DerridaHabermas Reader. Chicago, IL: University of Chicago Press, 161-175.

Jay, M. 2019. 'The Liberal Idea Has Become Obsolete': Putin, Geuss, and Habermas. The Point. https://thepointmag.com/criticism/the-liberal-ideahas-become-obsolete-putin-geuss-and-habermas/.

Kohn, M. 2000. 'Language, Power and Persuasion: Toward a Critique of Deliberative Democracy’. Constellations 7 (3): 408-429.

Koskenniemi, M. 2014. 'Vitoria and Us: Thoughts on Critical Histories of International Law'. Rechtsgeschichte - Legal History 22: 119-138.

McKean, B. 2016. 'What Makes a Utopia Inconvenient? On the Advantages and Disadvantages to a Realist Orientation to Politics'. American Political Science Review 110 (4): 876-888.

Mouffe, C. 2005. The Democratic Paradox. New York: Verso.

Müller-Doohm, S. 2016. Habermas: A Biography, trans. D. Steuer. Cambridge: Polity Press.

Newey, G. 2001. After Politics: The Rejection of Politics in Contemporary Liberal Philosophy. New York: Palgrave.

Philp, M. 2007. Political Conduct. Cambridge, MA: Harvard University Press.

Philp, M. 2012. 'Realism Without Illusions'. Political Theory 40 (5): 629-649.

Prinz, J. 2020. 'Realism in Political Theory, Ethnographic Sensibility, and the Moral Agency of Bureaucrats'. Polity 52 (1): 64-87.

Rossi, E. 2019. 'Being Realistic and Demanding the Impossible'. Constellations 26 (4): 638-652.

Sabl, A. and Sagar, R. 2017. Introduction. Critical Review of International Social and Political Philosophy. 20 (3): 269-277.

Scheuerman, W. 2002. 'Between Radicalism and Resignation: Democratic Theory', in R. von Schomberg and K. Baynes (eds), Discourse and Democracy: Essays on Habermas's Between Facts and Norms. Albany: SUNY Press, 61-85.

Scheuerman, W. 2012. 'Good-Bye to Radical Reformism?' Political Theory 40 (6): 830-838.

Scheuerman, W. 2013. 'The Realist Revival in Political Philosophy, or: Why New is not Always Improved'. International Politics 50 (6): 798-814.

Schlosser, J. 2014. 'Herodotean Realism'. Political Theory 42 (3): 239-261.

Shapiro, I. 2016. Politics Against Domination. Cambridge, MA: Harvard University Press.

Sleat, M. 2013. Liberal Realism: A Realist Theory of Liberal Politics. Manchester: Manchester University Press. 
Sleat, M. 2014. 'Legitimacy in Realist Thought: Between Moralism and Realpolitik'. Political Theory 42 (3): 314-337.

Sleat, M. 2016. 'The Value of Global Justice: Realism and Moralism'. Journal of International Political Theory 12 (2): 169-184.

Sleat, M. 2018. 'Introduction: Politics Recovered - On the Revival of Realism in Contemporary Political Theory', in M. Sleat (ed), Politics Recovered: Realist Thought in Theory and Practice. New York: Columbia University Press, 1-25.

Specter, M. 2010. Habermas: An Intellectual Biography. Cambridge: Cambridge University Press.

Specter, M. 2019. 'From Eclipse of Reason to the Age of Reasons? Historicizing Habermas and the Frankfurt School'. Modern Intellectual History 16 (1): 321-337.

Strecker, D. 2012. Logik der Macht: Zum Ort der Kritik zwischen Theorie und Praxis. Göttingen: Velbrück Wissenschaft.

Szücs, G. 2020. 'Aristotle's Realist Regime Theory'. European Journal of Political Theory 19 (2): 228-249.

Thaler, M. 2018a. 'Hope Abjuring Hope: On the Place of Utopia in Realist Political Theory'. Political Theory 46 (5): 671-697.

Thaler, M. 2018b. Naming Violence: A Critical Theory of Genocide, Torture, and Terrorism. New York: Columbia University Press.

Thaler, M. 2019. 'Peace as a Minor, Grounded Utopia: On Prefigurative and Testimonial Pacifism'. Perspectives on Politics 17 (2): 1003-1018.

Thomassen, L. 2007. 'Within the Limits of Deliberative Reason Alone: Habermas, Civil Disobedience and Constitutional Democracy'. European Journal of Political Theory 6 (2): 200-218.

Verovšek, P. 2019. 'A Case of Communicative Learning?: Rereading Habermas's Philosophical Project through an Arendtian Lens'. Polity 52 (3): 597-627.

Von Schomberg, R and Baynes, K. 2002. 'Introduction', in R. von Schomberg and K. Baynes (eds), Discourse and Democracy: Essays on Habermas's Between Facts and Norms. Albany: SUNY Press, 1-11.

White, S. 2018. 'Book Review: Habermas: A Biography, by Stefan MüllerDoohm'. Political Theory 46 (6): 963-970.

White, S. and Farr, E. 2012. 'No Saying' in Habermas. Political Theory 40 (1): 32-57.

Williams, B. 2005. In the Beginning Was the Deed: Realism and Moralism in Political Argument. Princeton, NJ: Princeton University Press.

Žižek, S. 1999. 'Carl Schmitt in the Age of Post-Politics', in C. Mouffe (ed), The Challenge of Carl Schmitt. New York: Verso: 18-37. 